音声言語医学 $58: 333-338,2017$

原 著

\title{
歌唱者における上咽頭炎による音声障害
}

\author{
楠山 敏行 ${ }^{1)}$ 池田 俊也 ${ }^{2)}$ 中川 秀樹3,1) \\ 沢田 亚弓 ${ }^{1)}$ 木村 晋太 ${ }^{4)}$
}

\begin{abstract}
要 約：音声障害を訴える歌唱者のなかで急性上気道炎症状を伴わない慢性上咽頭炎（以下 上咽頭炎）が原因と思われる症例に対して $1 \%$ 塩化亜鉛による上咽頭処置（B スポット療法） を行い, その治療効果を検討した。過去 1 年 7 カ月間に B スポット療法前後に内視鏡検查, 音声検查, Voice Handicap Index-10（VHI-10）拈よび Singing Voice Handicap Index-10 （SVHI-10）による評価が可能であった歌唱者 53 例を対象とした。内視鏡所見，VHI-10, SVHI-10，および最長発声持続時間における有意な改善を認めた. SVHI-10 減少幅が 5 以上の 症例は 41 例で $78 \%$ の改善率であった，以上より上咽頭炎は音声障害の原因疾患の一つと考え られ，B スポット療法は上咽頭炎による音声障害に対し有効であることが示唆された。また， その病態は自律神経系に関連する喉頭潤滑障害と上咽頭の共鳴障害であると考察した.
\end{abstract}

索引用語 : 上咽頭炎, 音声障害, 歌手, SVHI-10, 自律神経

\section{A Clinical Study of Cases of Singers with Voice Disorder Caused by Nasopharyngitis}

\author{
Toshiyuki Kusuyama ${ }^{1)}$, Shunya Ikeda², Hideki Nakagawa ${ }^{3,1}$, \\ Ayumi Sawada ${ }^{1)}$ and Shinta Kimura ${ }^{4)}$
}

\begin{abstract}
Objectives: In the course of the past 1 year and 7 months, 53 patients, all singers with vocal disorder whose cause was thought to be nasopharyngitis, were examined and treated at Tokyo Voice Clinic. In this presentation, the relation between nasopharyngitis and voice disorder was discussed by studying the clinical records of these 53 patients.

Materials and Methods: The study involved an analysis of 53 patients (13 males, 40 females, 19 to 86 years of age; mean age, 49 years). In all patients, otolaryngological, phoniatric and endoscopic examinations, and evaluations by the Voice Handicap Index-10 (VHI-10) and the Singing Voice Handicap Index-10 (SVHI-10) were completed. Treatment was carried out by direct application of $1 \%$ zinc chloride solution. The clinical records of the patients were
\end{abstract}

東京ボイスクリニック ${ }^{1)}$ ： $\mp 108-0075$ 東京都港区港南 2-6-7 大善ビル 7 階

国際医療福祉大学医学部公衆衛生学 ${ }^{2)}:$ T 286-8686 千葉県成田市公津の杜 4 丁目 3

聖母病院耳鼻咽喉科 ${ }^{3)}$ ：干161-8521 東京都新宿区中落合 2-5-1

株式会社アニモ ${ }^{4)}$ ： テ231-0015 神奈川県横浜市中区尾上町 2-27 大洋建設関内ビル 4F

${ }^{1)}$ Tokyo Voice Clinic: 2-6-7 Konan, Minato-ku, Tokyo 108-0075, Japan

${ }^{2}$ Department of Public Health, School of Medicine, International University of Health and Welfare: 4-3 Kozunomori, Narita, Chiba 286-8686, Japan

${ }^{3}$ Department of Otorhinolaryngology, International Seibo Hospital: 2-5-1 Nakaochiai, Shinjuku-ku, Tokyo 161-8521, Japan

${ }^{4)}$ Animo Limited: 2-27 Onoe-cho, Naka-ku, Yokohama, Kanagawa 231-0015, Japan

2016 年 11 月 18 日受稿 2017 年 3 月 10 日受理 
statistically studied for comparison between pre- and post-therapeutic data.

Results: Endoscopic findings, VHI-10, SVHI-10, and maximum phonation time (MPT) improved significantly. In 41 of the 53 patients SVHI-10 showed a decrease $\geq 5$ points. The improvement rate was $78 \%$.

Discussion and Conclusions: Nasopharyngitis is one of the diseases that cause voice disorder in singers with no organic lesion of the vocal folds. Treatment by direct application of $1 \%$ zinc chloride solution was effective. The pathology of nasopharyngitis was thought to be insufficiency of lubrication of the larynx due to dysfunction of the autonomic nerve system and resonant disorder of the nasopharynx.

Key words: nasopharyngitis, voice disorders, singers, SVHI-10, autonomic nerve system

\section{はじめに}

上咽頭は外界からの異物侵入の最初の門戸であり， 細菌やウイルスといった微生物やアレルゲンなど種々 の抗原刺激に晒されていると同時に，生体における異 物排除のための防御機能を有する ${ }^{1)}$. 急性上咽頭炎は 感冒などの上気道炎や咽喉頭炎に急性炎症として合併 し，局所の疼痛や灼熱感として自覚するが，慢性上咽 頭炎は長期にわたる咳嗽や咽喉頭異常感などいわゆる 不定愁訴の原因となり，診断に難渋することが多い22.

堀口は $1 \%$ 塩化亜鉛溶液による上咽頭処置を「B ス ポット療法」と称し，上咽頭炎に対するきわめて有効 な治療法として推奨した ${ }^{3}$.

われわれは音声障害の原因の一つとして上咽頭炎に 注目した。今回，音声障害を主訴に受診した症例のう ち急性上気道炎症状を伴わない慢性上咽頭炎（以下上 咽頭炎）が原因と考えられる歌唱者に対してB スポッ 卜療法を行い, その治療前後の所見を比較することに より上咽頭炎と音声障害の関連性について検討した。

\section{対象と方法}

対象は平成 25 年 6 月から 26 年 12 月までの 1 年 7 カ 月間に上咽頭炎と診断し B スポット療法を施行した 音声障害を訴える歌唱者のなかで，治療前後に内視鏡 検査，音声検査，VHI-10 $0^{4)}$ および SVHI-105) が可能で あった 53 例（男性 13 例, 女性 40 例, 年齢 19〜86 歳, 平均年齢 49 歳）である。本研究で対象にした歌唱者 には，歌を趣味にしている患者から職業歌手まで含ま れる，声の職業性の内訳を表 1 に示す，趣味で歌唱が 最も多く 27 例, 職業歌手 12 例, 歌手志望 6 例, 音楽 講師 4 例の順であった。

今回の研究で対象とした上咽頭炎の診断は, 内視鏡 検査によって喉頭および中下咽頭に器質的疾患を認め ない症例のなかで，上咽頭粘膜の発赤，腫脹，上咽頭
に由来する後鼻漏のいずれかを認める症例，または咽 喉頭異常感, 咽頭痛, 咽頭乾燥感のいずれかを訴える 症例とした。

B スポット療法は原則的に週 1 回施行し, 処置回数 が 10 回または 20 回程度となる約 2 カ月後または約 4 カ 月後に評価を行った。評価の内容として治療前後の内 視鏡検査, 空気力学的発声機能検査として最長発声持 続時間（MPT: Maximum Phonation Time）, 呼気流 率（MFR: Mean Flow Rate）, 声の強さ（SPL: Sound Pressure Level）を，音響分析検査として周期変動指 数 (PPQ: Pitch Perturbation Quotient), 振幅変動指 数 (APQ: Amplitude Perturbation Quotient)，規格 化雑音エネルギー（NNE: Normalized Noise Energy） を，自覚的評価として VHI-10 およびSVHI-10を検討 した。内視鏡検査は鼻咽喉電子スコープ（富士フイル ム：ER-530）を使用した。 上咽頭粘膜の発赤, 腫脹, 上咽頭に由来する後鼻漏の 3 項目を高度 (2), 軽度 (1), なし（0）で評価した。無関位発声に扔ける持続発声 母音を検査サンプルとし, 空気力学的発声機能検査は 永島医科器械社製発声機能検査装置 PS-77E を使用し た。音響分析はケイペンタックス製音響分析装置コン ピュータースピーチラボCSL4500 を使用して音声を ファイルに録音し，アニモ社で作成した研究用音声分 析プログラムで分析した ${ }^{6,7)}$. VHI-10 は音声言語医学

表 1 声の職業性の内訳

\begin{tabular}{lc}
\hline \multicolumn{1}{c}{ 声の職業性 } & 症例数 \\
\hline 歌唱 (趣味) & 27 \\
職業歌手 & 12 \\
歌手志望 & 6 \\
音楽講師 & 4 \\
声優 (含歌唱) & 1 \\
接客 (含歌唱) & 1 \\
教諭 (幼稚園) & 1 \\
声優 (含歌唱) 志望 & 1 \\
\hline
\end{tabular}


会推奨版を使用し，SVHI-10 はわれわれが翻訳し使用 した (表 2)、VHI-10 およびSVHI-10 で減少幅が 5 以 上を有効例とした。

内視鏡所見，VHI-10 およびSVHI-10に関する検討 にはウィルコクソン符号付順位検定を用い，その他の 検討には対応のある $\mathrm{t}$ 検定を用いた。

原則として声の衛生指導を行い，B スポット療法後 に鼻ネブライザーを行った。

\section{結果}

希望や都合により約 1 カ月後に評価した症例を 4 例 認めた。約 2 カ月後に評価を行った 42 例中 4 例はさ らに約 2 力月間治療を継続後に再度評価を行い, 再評 価デー夕を採用した． 6 例は 2 カ月後の評価を希望せ ずささらに 2 カ月治療を継続した後に評価を行った。 1 例は 13 回の治療に 7 力月を要した。平均処置回数 は 11.5 回（4-30 回），平均治療期間は 2.8 力月（0.8力 月-7 カ月) であった。

主訴は嗄声（会話および歌唱）, 嗄声（歌唱のみ）, 発声困難感(歌唱のみ), 発声困難感(会話および歌唱), 共鳴障害の順に認めた。その他の症状としては咽喉頭 異常感，痰，咳払い，声が続かない，声が裏返る，咽
頭痛などの順に認めた（表 3).

治療により主訴は 53 例中 52 例に改善を認めた（表 4).

内視鏡所見では, 上咽頭粘膜の発赤, 腫脹, 上咽頭 に由来する後鼻漏すべてにおいて有意に改善した（表 5）。上咽頭粘膜の発赤，腫脹いずれかを認めた症例は 治療前に 33 例 $(62 \%)$, 治療後に 24 例 $(45 \%)$ であっ た。上咽頭に由来する後鼻漏は治療前に 50 例 (94\%) に認め，治療後に 42 例（79\%）に認めた。

表 3 症状の内訳

\begin{tabular}{lclc}
\hline \multicolumn{1}{c}{ 主訴 } & 症例数 & 主訴以外の症状 & 症例数 \\
\hline 嗄声 (会話·歌唱) & 17 & 咽喉頭異常感 & 16 \\
嗄声 (歌唱) & 16 & 痰 & 11 \\
全音域 & 8 & 発声困難感 & 9 \\
高音 & 4 & 咳払い & 8 \\
中高音 & 1 & 声が続かない & 6 \\
途中から & 3 & 声が裹返る & 5 \\
発声困難感 (会話·歌唱) & 6 & 咽頭痛 & 5 \\
発声困難感 (歌唱) & 11 & 共鳴障害 & 5 \\
全音域 & 4 & 咽頭乾燥感 & 4 \\
高音 & 4 & 咳 & 4 \\
中低音 & 2 & 音程不安定 & 3 \\
低音 & 1 & & \\
共鳴障害 & 3 & & \\
\hline
\end{tabular}

表 2 歌声に関する質問紙（SVHI-10）

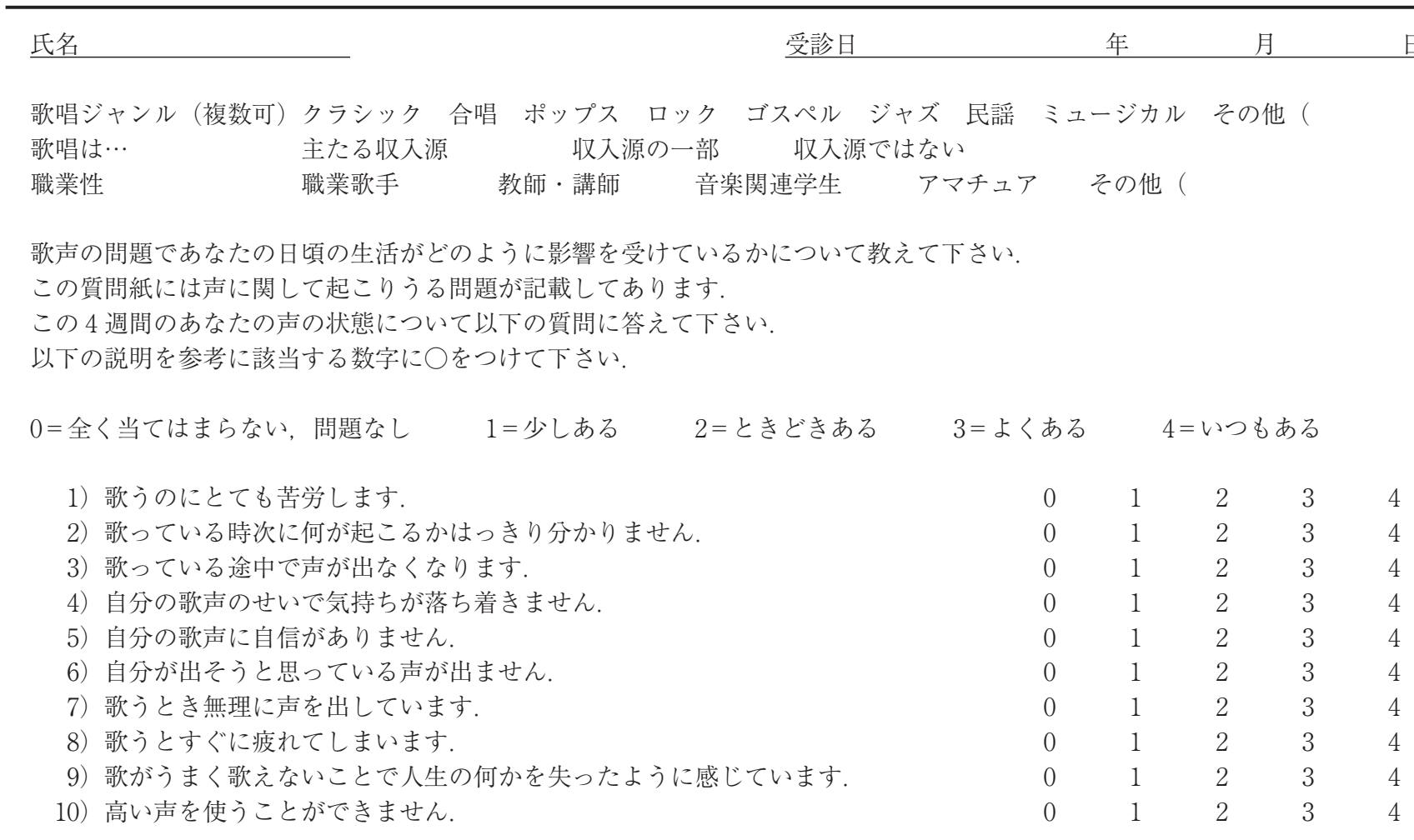

$\underline{\underline{\text { SVHI}}-10=}$ 
表 4 主訴の経過

\begin{tabular}{lrcccc}
\hline \multicolumn{1}{c}{ 主訴 } & 症例数 & 消失 & 改善 & $\begin{array}{c}\text { 軽度 } \\
\text { 改善 }\end{array}$ & 不変 \\
\hline 嗄声 (会話·歌唱) & 17 & 5 & 9 & 3 & \\
嗄声 (歌唱) & 16 & & & & \\
$\quad$ 全音域 & 8 & 2 & 5 & 1 & \\
高音 & 4 & 2 & & 2 & \\
中高音 & 1 & 1 & & & \\
$\quad$ 途中から & 3 & 1 & 1 & & 1 \\
発声困難感 (会話·歌唱) & 6 & & 4 & 2 & \\
発声困難感 (歌唱) & 11 & & & & \\
$\quad$ 全音域 & 4 & & 2 & 2 & \\
高音 & 4 & 2 & 1 & 1 & \\
中低音 & 2 & 1 & & 1 & \\
低音 & 1 & & & 1 & \\
共鳴障害 (歌唱) & 3 & 1 & 1 & 1 & \\
\hline
\end{tabular}

表 5 内視鏡検査結果

\begin{tabular}{|c|c|c|c|c|}
\hline & \multicolumn{3}{|c|}{ 重症度 } & \multirow{2}{*}{$\begin{array}{l}\text { ウィルコクソン符 } \\
\text { 号付順位検定 } \mathrm{p} \text { 值 }\end{array}$} \\
\hline & 2 & 1 & 0 & \\
\hline 上咽頭粘膜の発赤 & & & & $\mathrm{p}=0.030$ \\
\hline 治療前 & 6 & 17 & 30 & \\
\hline 治療後 & 1 & 15 & 37 & \\
\hline 上咽頭粘膜の腫脹 & & & & $\mathrm{p}<0.001$ \\
\hline 治療前 & 10 & 17 & 26 & \\
\hline 治療後 & 3 & 11 & 39 & \\
\hline 上咽頭に由来する後鼻漏 & & & & $\mathrm{p}<0.001$ \\
\hline 治療前 ～～～～～～～ & 8 & 42 & 3 & \\
\hline 治療後 & 1 & 41 & 11 & \\
\hline
\end{tabular}

表 6 VHI-10 および SVHI-10 の結果

\begin{tabular}{lcc}
\hline & VHI-10 & SVHI-10 \\
\hline 治療前平均值 & 7.94 & 21.85 \\
治療後平均值 & 5.49 & 11.79 \\
ウイルコクソン符号 & 0.008 & $<0.001$ \\
付順位和検定 p 值 & & \\
& 有意差あり & 有意差あり \\
\hline
\end{tabular}

VHI-10 は $7.94 \pm 8.85$ から $5.49 \pm 6.95$ へ, SVHI-10 は $21.85 \pm 10.29$ から $11.79 \pm 10.36$ へと有意に低下した (表 6).VHI-10 で減少幅が 5 以上の症例は 53 例中 10 例と $19 \%$ で認め, SVHI-10 に抒いては 53 例中 41 例 と $78 \%$ で認めた.

空気力学的検查結果の平均值は治療前でも正常範囲 に含まれていた．MPTのみは $18.9 \pm 7.72$ 秒から 20.7 土8.89 秒と有意に延長したが, MFR, SPL は治療前 後で有意差を認めなかった（表 7).MPT は全症例の 平均值が 18.9 秒から治療後に 20.7 秒と $10 \%$ の延長で あったが, 声が続かないという症状を訴えた 6 例に限 ると平均 13.3 秒から 19 秒と $46 \%$ の著明な延長を認め た (表 8).
表 7 空気力学的検査結果

\begin{tabular}{lccc}
\hline & $\begin{array}{c}\text { MPT } \\
(\mathrm{sec})\end{array}$ & $\begin{array}{c}\text { MFR } \\
(\mathrm{ml} / \mathrm{s})\end{array}$ & $\begin{array}{c}\mathrm{SPL} \\
(\mathrm{dBspl})\end{array}$ \\
\hline 前平均值 $\pm \mathrm{SD}$ & $18.9 \pm 7.7$ & $155.8 \pm 69.4$ & $74.8 \pm 5.3$ \\
後平均值 $\pm \mathrm{SD}$ & $20.7 \pm 8.9$ & $153.5 \pm 73.6$ & $75.0 \pm 5.1$ \\
$\mathrm{t}$ 検定 $\mathrm{p}$ 值 & 0.020 & 0.785 & 0.741 \\
& 有意差あり & 有意差なし & 有意差なし \\
\hline
\end{tabular}

表 8 声が続かないという症状を訴 えた 6 例におけるMPTの結果

\begin{tabular}{ccc}
\hline 症例 & $\begin{array}{c}\text { 治療前 } \\
(\mathrm{sec})\end{array}$ & $\begin{array}{c}\text { 治療後 } \\
(\mathrm{sec})\end{array}$ \\
\hline 22 & 8 & 11 \\
23 & 6 & 11 \\
24 & 20 & 31 \\
27 & 16 & 24 \\
28 & 15 & 16 \\
37 & 15 & 21 \\
平均 & 13.3 & 19 \\
\hline
\end{tabular}

表 9 音響分析結果

\begin{tabular}{lccc}
\hline & $\mathrm{PPQ}(\%)$ & $\mathrm{APQ}(\%)$ & $\mathrm{NNE}(\mathrm{dB})$ \\
\hline 前平均值 $\pm \mathrm{SD}$ & $0.73 \pm 0.75$ & $0.77 \pm 0.68$ & $-23.7 \pm 3.59$ \\
後平均值 $\pm \mathrm{SD}$ & $0.62 \pm 0.57$ & $0.69 \pm 0.41$ & $-23.96 \pm 4.15$ \\
$\mathrm{t}$ 検定 $\mathrm{p}$ 值 & 0.257 & 0.370 & 0.593 \\
& 有意差なし & 有意差なし & 有意差なし \\
\hline
\end{tabular}

音響分析は 50 例に行った. $\mathrm{PPQ}, \mathrm{APQ}, \mathrm{NNE}$ す べてにおいて治療前でも正常範囲に含まれており，平 均值の低下を認めるも有意差はなかった（表 9).

\section{考察}

\section{1 . 上咽頭炎の診断について}

上咽頭炎の明確な診断基準はない。症状や所見と組 織検査結果の関係を検討したうえで正確な診断基準が 作成されるべきであるが，一般診療では上咽頭粘膜の 発赤や腫脹，あるいは上咽頭に由来する後鼻漏などの 所見により上咽頭炎と診断される。しかしながら，こ れらの所見は無症状者にも認めることが多い.

今回の研究では前述したように, 内視鏡検査によっ て喉頭および中下咽頭に器質的疾患を認めない症例の うち，上記の上咽頭所見のいずれかを認める症例，ま たは咽喉頭異常感, 咽頭痛, 咽頭乾燥感のいずれかを 訴える症例を上咽頭炎と診断した。

従来，上咽頭炎は塩化亜鉛溶液を含んだ咽頭捲綿子 を上咽頭に塗布した際に出血や擦過痛を伴うことから 判定されてきた ${ }^{33}$. 大野らは硬性内視鏡を用いて上咽 頭の発赤と腫脹のレベルにより上咽頭炎を重症度分類 し，B スポット療法による治療効果を報告した8)。彼 
らは内視鏡により上咽頭の炎症レベルを評価可能とし ている，倉田は上咽頭に関連すると考えられる訴えを もつ症例に鼻咽喉ファイバースコープによる上咽頭内 視鏡検査を施行し 8 割以上に炎症所見を認める一方 で，訴えのない症例に同検査を行った場合も約 6 割に 慢性炎症像を認めたと報告した ${ }^{9)}$ 。今回，上咽頭粘膜 の発赤, 腫脹, および上咽頭に由来する後鼻漏を検討 し，すべてにおいて治療後に有意な改善を認めた。し かしながら，治療前に上咽頭粘膜の発赤，腫脹のいず れかを認めた症例は $62 \%$ にすぎず，上咽頭に由来す る後鼻漏は治療前に 50 例（94\%）に認めるも，治療 後も 42 例 $(79 \%)$ に認めている.

すなわち, 内視鏡による治療前後の所見の比較は可 能であるものの，上咽頭炎と診断することは決して容 易ではなく，詳細な問診を組み合わせた判断が不可久 と思われる。

\section{2. 今回の検査結果について}

近年, 音声障害患者の QOL の観点から自身の自覚 的評価として 30 項目からなる VHI が開発され ${ }^{10)}$ ，そ の短縮版である 10 項目からなるVHI-10 も報告され た。さらには歌唱者における声の問題がVHI では反 映されないことから SVHI ${ }^{11)}$ およびSVHI-10 も開発 されている. 城本らにより日本語版 VHI とその短縮 版 VHI-10の信頼性と妥当性は検証されている ${ }^{12}$.

われわれの検査結果においては, VHI-10, SVHI-10 ともに有意な減少を認めた。改善率はVHI-10での減 少幅が 5 以上を有意とする先行論文 ${ }^{13)}$ を参考とし, SVHI-10においても同様に評価した. SVHI-10では 78\%の改善率を認めるも, VHI-10では 19\%となった。 今回の検討では，主訴は 53 例全例において歌唱が関 与し, かつ治療後 1 例を除き 52 例に改善を認め, 歌 唱者に打けるSVHI-10の有用性を示す結果となった。

無関位発声という発声条件を定めても, 空気力学的 検査での測定值にはある程度の幅があり, 正常域の中 に含まれている值の変動から治療効果を評価すること は困難である。しかし，MPT は発声時の最大能力を 反映するパラメーターであり, 今回の研究で有意な延 長を認めたことは意義が高い.

今回の症例のように空気力学的発声機能検査や音響 分析検査で明らかな異常がなくても, 多彩な症状を呈 する場合は上咽頭炎による音声障害の可能性を念頭に おくと同時に, SVHI-10の評価を加え詳細な問診を取 ることが肝要と思われる。

\section{3 . 上咽頭炎による音声障害について}

山崎は鼻咽頭部に異常感を訴える者の多くに自律神
経失調症状を多く認めることから鼻咽頭は自律神経系 の特殊刺激部位であるとした ${ }^{14)}$ 。また，これらの症候 を有する場合を「鼻咽頭症候群あるいは鼻咽頭症候」 と称し, その症状の一つに「談話中嗄声または話しに くい」を挙げている.

竹内はウサギの上咽頭と煩粘膜に自律神経作動薬を 注射後, 身体各部の組織変化を観察し, 上咽頭は自律 神経系の特殊刺激部位であることを実験的に示し $た^{15)}$

堀口は自律神経機能評価法の一つである指尖脈波を 用いて上咽頭炎症例の治療前後の検討を行った，上咽 頭刺激を行った直後には，指尖脈波において血流量の 低下と変動の縮小が一時的に見られる。その回復まで の時間は上咽頭炎の患者では遅延し, B スポット療法 を続けることにより正常化することから，上咽頭炎は 自律神経を介した反射が関与するとしだ)、香取は上 咽頭炎の患者にBスポット療法を施行し, 治療前後 に自律神経機能検査の一つであるメコリールテストを 施行したところ, 交感神経優位から正常パターンに改 善したと報告した ${ }^{16)}$.

上咽頭は自律神経系と関連性があり，上咽頭炎では 交感神経優位であるとすると, 喉頭潤滑は低下し, 上 咽頭炎による音声障害の病態に関与していると考えら れる。喉頭潤滑と音声の関連性については過去より多 くの報告がある. Nakagawa らは成犬摘出喉頭による 吹鳴実験において気道液に高粘度液を使用したときに 声帯振動の遅れと振動軌跡の縮小を認めたと報告し た ${ }^{17)}$. Hemler らは羊の声帯粘膜切片をバイブレーター で振動させ，相対湿度 $0 \%$ および 100\%の環境下で粘 性㧍よびスティフネスを計測し，相対湿度 $0 \%$ で声带 粘膜の粘性抢よびスティフネスが有意に増大すると報 告した ${ }^{18)}$ 。彼らはまた正常人を対象に相対湿度 0$100 \%$ の空気を経口的に吸入した後の音響分析を施行 し, 周期変動指数, 振幅変動指数ともに相対湿度 $0 \%$ の空気で有意な増大を認めたと報告した ${ }^{19}$. Sivasankar らは低湿度の大気中での口呼吸と鼻呼吸 を比較し, 発声に必要な声門下圧が口呼吸後に有意に 増大寸るとした ${ }^{20)}$.いずれも喉頭潤滑の低下が引き起 こす音声障害を説明している.

また, 上咽頭は共鳴器官の一部であるため, 上咽頭 炎による上咽頭粘膜の腫脹や粘性の高い分泌物の付着 などが直接共鳴に影響をきたすと考えられる。

以上より上咽頭炎は音声障害の原因疾患の一つであ り，またその病態は自律神経系に関連する喉頭潤滑障 害，および上咽頭の共鳴障害であると考察した，歌唱 
者の音声障害で声帯に著変を認めない場合には念頭に おくべき疾患の一つといえよう.

\section{まとめ}

音声障害を訴える歌唱者のなかで上咽頭炎が原因と 思われる症例にB スポット療法を施行し, 治療前後 の評価を行った．SVHI-10による評価で 78\%の有意 な改善率を認めた。上咽頭炎に起因する音声障害の病 態として自律神経系に関連する喉頭潤滑障害および共 鳴障害であると考察した。

本稿の要旨は第 60 回日本音声言語医学会学術講演会 (2015 年 10 月, 名古屋市) に打いて口演発表した.

利益相反自己申告：申告すべきものなし．

\section{文献}

1）川内秀之：上気道粘膜の生体防御機構と炎症性疾患の病態 と治療。耳展，43 (1)：10-22，2000.

2) 原㴊保明, 岸部 幹: 耳鼻咽喉科外来診療 私の工夫 扁桃 処置と上咽頭処置. ENTONI, $113: 91-98,2010$.

3）堀口申作：全身諸疾患と耳鼻咽喉科一特に鼻咽腔炎につい て一. 日耳鼻, 補 $1: 1-82,1966$.

4) Rosen CA, Lee AS, Osborne J, et al: Development and validation of the voice handicap index-10. Laryngoscope, 114: 1549-1556, 2004.

5) Cohen S, Statham M, Rosen C, et al: Development and validation of the singing voice handicap-10. Laryngoscope, 119: 1864-1869, 2009.

6）粕谷英樹：病的音声の音響分析．新編 声の検査法（日本 音声言語医学会編), 医歯薬出版, 東京, 223-232 頁, 2009.

7) Kasuya H, Ogawa S, Mashima K, et al: Normalized noise energy as an acoustic measure to evaluate pathological voice. J Acoust Soc Am, 80 (5): 1329-1334, 1986.

8）大野芳裕, 國弘幸伸：上咽頭炎に対する局所療法の治療効 果一自覚症状㧍よび硬性内視鏡による局所所見の評価一. 耳展, 42(1)：50-56, 1999.

9）倉田響介：上咽頭病態の臨床的研究一内視鏡所見を中心に
一. 耳鼻臨床，86 (8)：1175-1185，1993.

10) Jacobson B, Johnson A, Grywalski C, et al: The voice handicap index (VHI): Development and validation. Am J Speech Lang Pathol, 6 (3): 66-70, 1997.

11) Cohen S, Jacobson BH, Garrett CG, et al: Creation and validation of the singing voice handicap index. Ann Otol Rhinol Laryngol, 116 (6): 402-406, 2007.

12）城本 修, 折舘伸彦, 生井友紀子, 他：推奨版 VHI 拉上 びVHI-10 の信頼性と妥当性の検証一多施設共同研究一. 音声言語医学, $55 ： 291-298,2014$.

13) Mallur PS, Morrison MP, Postma GN, et al: Safety and efficacy of carboxymethylcellulose in the treatment of glottic insufficiency. Laryngoscope, 122: 322-326, 2012.

14）山崎春三：鼻咽頭症候群，症候と該部に関する病理学的研 究. 日耳鼻, $67 ： 1663-1668,1964$.

15）竹内治一：鼻咽喉側壁に注射せる自律神経毒の全身半側性 に扮よぼす影響について。耳鼻臨床，52（7）：754-782, 1959.

16）香取早苗：鼻咽腔炎の自律神経学的研究. 日耳鼻, 72 : 1728-1758, 1969.

17) Nakagawa H, Fukuda H, Kawaida M, et al: Lubrication mechanism of the larynx during phonation: an experiment in excised canine larynges. Folia Phoniatr Logop, 50 (4): 183-194, 1998.

18) Hemler RJ, Wieneke GH, Lebacq J, et al: Laryngeal mucosa elasticity and viscosity in high and low relative air humidity. Eur Arch Otorhinolaryngol, 258 (3): 125129, 2001.

19) Hemler RJ, Wieneke GH and DeJonckere PH: The effect of relative humidity of inhaled air on acoustic parameters of voice in normal subjects. J Voice, 11 (3): 295-300, 1997.

20) Sivasankar M and Fisher KV: Oral breathing increases Pth and vocal effort by superficial drying of vocal fold mucosa. J Voice, 16 (2): 172-181, 2002.

\author{
別刷請求先： $=108-0075$ 東京都港区港南 2-6-7 \\ 大善ビル 7 階 \\ 東京ボイスクリニック \\ 楠山敏行
}

